\title{
O cuidado do presente como entrave para a construção do sentido da existência, em $O$ amanuense Belmiro
}

Edson Ribeiro da Silva"

\section{Resumo}

Bakhtin trata da natureza plurilinguística do romance, atentando para a assimilação que este faz de gêneros diversos. O formato de diário permite ao romance atentar para o presente, aproximando a narrativa do cotidiano, e resulta na incompletude própria daquele gênero. Se o cuidado de si possibilita o reconhecimento da própria identidade, conforme Foucault, o diário, voltado para o presente, exemplifica momentos desse cuidado. Heidegger, no entanto, aponta o cuidado do presente como entrave para a constituição de um ser autêntico, cuja existência faça sentido; apenas a atenção para o futuro, como projeto de ser, pode libertar o ser da impessoalidade do cotidiano. Essa natureza contraditória do diário é observada, aqui, no romance $O$ amanuense Belmiro, de Cyro dos Anjos, que mostra um homem reflexivo. Nele, a ocupação com o cotidiano enclausura o ser na impessoalidade e gera o medo de realizar seu projeto. O ser fracassa e faz da ocupação com o presente um modo de suportar a falta de sentido da existência.

Palavras-chave: Diário. Cyro dos Anjos. Identidade. $O$ amanuense Belmiro.

\section{Introdução: romance e diário}

Muito já se escreveu acerca da constituição discursiva do romance, como gênero que, sem ter constituído um discurso específico, assume a liberdade de incorporar modalidades discursivas díspares, não só ligadas a outros gêneros literários como à linguagem convencional. O plurilinguismo do romance possibilita que ele assimile novas possibilidades de configuração, que fazem dele objeto de experimentações estéticas capazes de lhe garantir os efeitos de liquidez e de incompletude.

Bakhtin (2015) dedicou uma extensa atenção ao romance, que, antes dele, ainda não havia sido observado com tamanha abrangência em sua especificidade como configuração estética. O plurilinguismo

\footnotetext{
Professor do curso de mestrado em Teoria Literária da Uniandrade, em Curitiba, Paraná. Pós-doutor pela Universidade Estadual de Londrina. E-mail: edribeiro@uol.com.br
}

\footnotetext{
Data de submissão: fev. 2017 - Data de aceite: mar. 2017 http://dx.doi.org/10.5335/rdes.v13i1.6724
} 
trazia, entre outras possibilidades, a aproximação do romance com o presente, o inacabamento do tempo no qual as personagens ainda vivem ou o narrador emite a sua voz. Tratava-se de uma ruptura com a completude que caracterizava a epopeia, gênero ao qual o romance costuma ser atrelado. Portanto, era a atenção para a fluidez que levava Bakhtin a olhar para a configuração discursiva do romance. Não se tratava apenas de narrar, de uma voz assumir a enunciação de fatos já decorridos no tempo. O distanciamento no tempo e a completude do narrado, características fundamentais da epopeia, são possibilidades que o romance rejeita. Da mesma forma, rejeita a configuração da linguagem da epopeia como unitária. A atitude de contar, típica da epopeia, fazia com que todas as possibilidades discursivas passassem pelo crivo de uma voz unificadora: quem falava era o narrador como voz do autor.

O romance renuncia a essa unificação, mesmo quando ainda a preocupação em contar faz com que um narrador onisciente hierarquize as vozes que agora cabem na narrativa. Essa voz unificadora vai, conforme o gênero ganha popularidade e formatos novos, perdendo força diante das inúmeras vozes, das possibilidades de representação dos discursos de personagens e de gêneros não literários. Basta pensar na quantidade de gêneros inseridos em um romance como Tristram Shandy, de Sterne. Lá estão relatórios, bulas religiosas, gráficos, definições científicas, entre outros.
O esforço por intensificar formas de veridicção leva o romance, como ocorre em Tristram Shandy, a assumir a configuração de gêneros não literários, como a autobiografia, a carta, o diário. Trata-se, então, de uma passagem da voz de um narrador distanciado do narrado para uma enunciação em primeira pessoa. A possibilidade de um narrador falar de si aproxima ainda mais o romance do tempo presente. A narrativa que finge ser uma autobiografia relativiza a verdade do passado narrado, aproxima o narrador do leitor e assume um discurso que prefere dar peculiaridades à voz que enuncia, finge ser a linguagem da personagem. A existência de um eu confessional também significa uma ruptura, pois agora é o tom irônico que justifica que personagens identificadas como gente comum possam contar seu passado, nem sempre louvável. A troca de vozes, que assumem pontos de vista diferentes, implica também mudanças no aspecto discursivo. Se a assimilação dos discursos diversos, sejam de narradores ou personagens, ainda acontece de modo tímido, agindo o autor como um maestro que impede a dispersão dentro da continuidade do enredo, a modernidade se caracterizaria por um esforço por intensificar a natureza polifônica do romance. Ainda assim, o romance que assimilava a configuração de autobiografia possibilitava certo distanciamento em relação ao narrado, que se torna praticamente inexistente quando a forma assimilada é a do diário. 
Esse gênero assume a possibilidade não somente de pessoas comuns terem suas histórias narradas, confidenciadas ou confessadas por si, como de aproximar o tempo da narração e o da narrativa. A aproximação entre a narração (enunciação) e a narrativa (relato) intensifica a incompletude da personagem como sujeito. Não há, no diário, um lapso de tempo que permita a reflexão cuidadosa acerca do fato narrado. Assim, o herói-narrador aparece como problemático. Ele ainda não está de posse dos sentidos que o narrado assume para sua constituição como sujeito. Não existe a completude que a autobiografia busca, a visão de conjunto, nem a enunciação para um outro, que faz deste um elemento determinante para a narrativa em primeira pessoa que se volta para um receptor. O diário é monológico, no sentido de não representar um outro para quem se fala. Trata-se de um falso fechamento, que finge intensificar a sinceridade daquele que fala de si.

Bakhtin enumera algumas possibilidades de o romance incorporar discursos, ao tratar do caráter plurilinguístico do gênero:

O romance, tomado como um conjunto, caracteriza-se como um fenômeno pluriestilístico, plurilíngue e plurivocal. [...]

Eis os principais tipos de unidades estilísticas de composição nas quais o conjunto romanesco se decompõe habitualmente:

1. A narrativa direta e literária do autor (em todas as suas variedades multiformes);

2. A estilização de diversas formas da narrativa tradicional oral (skaz);
3. Estilizações de diversas formas da narrativa (escrita) semiliterária tradicional (cartas, diários, etc.);

4. Diversas formas literárias, mas que estão fora do discurso literário do autor: escritos morais, filosóficos, científicos, declamação, retórica, descrições etnográficas, informações protocolares, etc.;

5. Os discursos dos personagens estilisticamente individualizados. [...]

O discurso do autor, os discursos dos narradores, os gêneros intercalados, os discursos das personagens não passam de unidades básicas de composição com a ajuda das quais o plurilinguismo se introduz no romance (BAKHTIN, 2015, p. 74-75).

A ideia de decomposição indica uma intenção analítica do teórico russo. Aqui, interessa a composição, a configuração, pois é ela que possibilita que tais gêneros não literários tornem-se arte. $\mathrm{A}$ assimilação da forma, e não do conteúdo, desses gêneros diversos traz com ela as possibilidades não apenas discursivas, mas de obtenção de efeitos estéticos. Aceitar essas formas significa estar atento a suas especificidades enquanto gêneros próprios que, incorporados pela literatura, estabelecem possibilidades de elaboração estética e de interação com o leitor. O diário, por exemplo, como gênero originalmente monológico, desenvolve formatos próprios dentro do romance, que vão da mimetização mais fiel das suas especificidades até a ruptura com essas. O diário passa de um esforço por veridicção, com falsos prólogos, notas de editor, com datas específicas para cada trecho ou capítulo, chegando à ruptura com tudo isso. Tais possibilidades de aproximação ou ruptura com o gênero 
que está sendo assimilado é uma evidência da fluidez do romance.

\section{O diário como constituição do sujeito}

A identidade do sujeito é o reconhecimento de si mesmo através da memória. Aquela memória que Paul Ricoeur (2007, p. 27s), retomando Platão, chama de "eicástica", ou seja, conjunto de lembranças efetivamente vividas, sem a intervenção intencional da imaginação. Para Martin Heidegger (1996, p. 176s), o reconhecimento da identidade pode ser explicado pela fórmula estabelecida por Parmênides, ou seja, A=A. Entende-se por A o sujeito em um determinado momento de sua existência, fixado pela memória. É o conjunto daqueles elementos que tornam o sujeito reconhecível, o que o identifica entre os outros. No entanto, existe o tempo, no sentido de mudança incessante. A possibilidade de o sujeito, como A, reconhecer-se como tal após a ação do tempo significa que ele atenta para a própria igualdade de si consigo mesmo. A permanência de elementos reconhecíveis é reiteradamente considerada como identidade.

Nesse mesmo sentido, a autobiografia surge como forma narrativa que alia a mudança de estados do sujeito aos elementos permanentes dele. A ideia de a autobiografia explicar quem é o sujeito, como tal, aparece de forma enfática nas Confissões, tanto nas de Santo Agostinho quanto nas de Rousseau. Afirmar que se está mostrando como se é, de forma inteira, como insistia Rousseau, é uma intenção daquele que conta uma trajetória em que se permanece idêntico a si mesmo apesar das mudanças de quem está no tempo. O romance que assume a forma da autobiografia insiste nessa ideia. Assim, os narradores-protagonistas de Tom Jones, Moll Flanders, Tristram Shandy podem contar suas vidas, do nascimento até o momento próximo da narração, entendendo-se que há uma identidade na personagem narrada; ela é um sujeito. A mesma ideia dá origem, também, ao bildungsroman, romance de formação, em que a identidade é colocada como construção ao longo do tempo, até se chegar ao reconhecimento da personagem como é no instante próximo à narração. Se o romance de formação é escrito em primeira pessoa, fica evidente a intenção de observação da própria identidade como autoanálise. $\mathrm{O}$ sujeito que se volta para si mesmo, entendendo-se como formado ou incompleto, é motivo para a reflexão do narrador ensimesmado.

A diferença do formato da autobiografia para o do diário está no distanciamento em relação ao tempo da narração, ao presente em que aquele que enuncia se localiza. Se a primeira preserva a distância em relação a fatos que formam uma biografia, o outro é marcado pela atenção dada ao presente. Nesse sentido, o diário permanece como incompleto; se fizesse uso de uma estrutura narrativa convencional, perderia o caráter de acumulação de registros fortuitos. $\mathrm{O}$ formato 
de diário, quando transposto para o romance, acaba, por vezes, submetendo-se às suas estruturas reconhecíveis, como definir uma problemática e chegar a um desfecho para ela. Além disso, acaba por tornar-se uma forma de jogo baseada em um contrato de leitura que prefere fingir a incompletude a, efetivamente, acatá-la. Quando romance, o diário retoma a mesma preocupação da autobiografia: a fixação de uma identidade. Por intermédio do diário, o sujeito pode reconhecer-se, mesmo quando prefere fingir a dispersão. A sua eicástica não é composta de imagens da memória remota, mas da delimitação dos sentidos da memória recente. $\mathrm{O}$ que se busca, de um modo geral, é o reconhecimento daquele A como configuração reconhecível do sujeito, o que poderia implicar mais a atenção para os elementos estáveis daquele que narra do que para a mudança. No entanto, percebe-se como intensa a atenção que se dá à mudança nesse sujeito, mesmo que ela pareça ocorrer no tempo da produção do texto. Esta aparece, tantas vezes, como um obstáculo ao reconhecimento do ser, do eu, que deixa de observar-se para prestar atenção aos fatos que o condicionam. O diário, portanto, pode representar um momento de crise, até mesmo identitária. O exercício de atentar para si, por meio da palavra, pode ser por si mesmo uma possibilidade de reconhecimento.

Em $O$ pacto autobiográfico, Lejeune focaliza o diário como uma das formas de autobiografia. Deixando claro que é "para si que se escreve um diário: somos nossos próprios destinatários no futuro" (LEJEUNE, 2014, p. 302), o teórico define a intenção que motiva a sua elaboração: formar um acervo de dados da memória, para que ela possa ser conservada e depois reencontrada. Ou seja:

Além disso, a anotação cotidiana, mesmo que não seja relida, constrói a memória: escrever uma entrada pressupõe fazer uma triagem do vivido e organizá-lo segundo eixos, ou seja, dar-lhe uma "identidade narrativa" que tornará minha vida memorável. É a versão moderna das "artes da memória”, cultuadas na Antiguidade. O diário será ao mesmo tempo arquivo e ação, "disco rígido" e memória viva (LEJEUNE, 2014, p. 302).

O olhar para o passado, como forma de preservação da memória, certamente, é um pretexto para a restauração desse tempo perdido, no tempo presente, ou até mesmo para que um eventual leitor, no futuro, possa reconstituir a pessoa que anotou sua rotina. Embora essa possibilidade permaneça como hipótese, ou seja, o olhar do outro para aquele que escreveu sobre si, é notória a função do diário como espelho que reflete o ser e o torna reconhecível. Lejeune expõe essa função da seguinte maneira:

O papel é um espelho. Uma vez projetados no papel, podemos nos olhar com distanciamento. E a imagem que fazemos de nós tem a vantagem de se desenvolver ao longo do tempo, repetindo-se ou transformando-se, fazendo surgir as contradições e os erros, todos os vieses que possam abalar nossas certezas. É certo que só é possível viver com alguma autoestima, e o diário será, como a autobiografia, o espaço de construção dessa imagem positiva (2014, p. 303-304). 
A imagem positiva que Lejeune atrela à autobiografia, que pode ser uma celebração da personalidade de quem a escreve, aparece agora como uma possibilidade de construção. Ela não está pronta ainda. $O$ espelho pode ser o lugar onde o ser se acompanha ao longo do tempo, percebendo nas mudanças aqueles elementos constantes que compõem uma identidade. É preciso que se entenda identidade como uma significação para o ser. Reconhecer-se é inserir-se em um plano para a própria existência, torná-lo executável ou até vê-lo como fracassado. O conflito é característico do ser que olha para o espelho dentro de uma série de eventos no tempo. Os dias marcam a incompletude, a crise, elementos que podem impedir o reconhecimento de uma imagem estável. Lejeune, ainda sobre o diário, especifica:

\footnotetext{
Mas ele também pode ser espaço de análise, de questionamento, um laboratório de introspecção. No diário, o autorretrato nada tem de definitivo, e a atenção dada a si está sempre sujeita a desmentidos futuros. A aventura do diário é, portanto, muitas vezes vivida como uma viagem de exploração, ainda mais que esse conhecimento de si não é uma simples curiosidade, mas condiciona a continuação da viagem: é preciso escolher e agir (2014, p. 304).
}

Trata-se, portanto, de uma tomada de consciência, que se transforma em tomada de posição. A ação, no que se refere ao diário, projeta aquele $\mathrm{A}$, na qual o sujeito se reconhece, em uma dimensão futura, na qual ele mesmo quer reconhecer-se, com as alterações que seu ideal de vida deseja construir. O reconhecimento do que se é, no momento presente, e do que se foi, naquilo já registrado, constitui uma possiblidade de se acompanhar as mudanças refletidas no espelho e que indicam que a imagem idealizada está ou não em construção. $\mathrm{O}$ diário assume a condição não apenas de arquivo, mas de ata, que registra o estado presente para uma eventual comparação com o futuro.

$\mathrm{Na}$ análise que fez de Memorial de Aires, Adriana da Costa Teles aponta as estratégias que a adoção da forma de diário possibilita a Machado de Assis, como efeito de veridicção a atingir o leitor, que se vê diante de um texto que finge estar em construção, sem planejamento e sem desenlace. $O$ contato com o cotidiano assume o disfarce de falta de critério para a seleção dos fatos narrados. Eles acontecem, e o narrador é apenas lançado em meio a eles. Existe a mudança que imprecisa os contornos desse narrador, que, ao escrever um diário, é introvertido:

O papel do leitor em meio a esse suposto exercício de escrita íntima e de progressivo registro da realidade parece ser o de um voyeur. Violando a intimidade do enunciador, este entra em contato direto com seu cotidiano e, dessa forma, com os fatos que o diarista julgou importante registrar, as impressões que situações e pessoas lhe conferiram, suas reflexões, estados de espírito, enfim, com sua visão do universo vivenciado. $\mathrm{O}$ efeito da estratégia de simulação empregada por Machado leva o leitor a acreditar que pode, justamente pela natureza do relato, atingir a pureza mais profunda dos pensamentos do narrador e o apanhar nu, despojado de qualquer artifício, justamente pelo papel de voyeur que assume (TELES, 2009, p. 28).

Afinal, o voyeur leitor é apenas uma aparência, um efeito buscado pela forma adotada. O leitor-ideal sabe que os 
efeitos de despojamento, de nudez do narrador e de falta de planejamento são uma relação contratual, jogo que mimetiza a situação daquele que escreve o diário sem ter controle sobre as experiências que relata. Por isso, o registro das impressões, das reflexões, dos estados de espírito, que indica situacionalidade, cotidianidade que está em busca de um sentido para o vivido. Esse leitor-ideal sabe que, como convenção, o romance está constituindo um sentido. A pureza desse narrador que escreve para não ser lido possibilita que o leitor seja também o espelho no qual esse autor de diário fingido, ficcional, se reflete e se faz reconhecível. O Conselheiro Aires faz assim, e por isso o leitor pode dizer que o reconhece como um sujeito portador de especificidades que o identificam.

A possibilidade de desnudamento do ser faz lembrar o desvelamento, de que fala Heidegger (1996), através do qual surge o reconhecimento de si. O diário, incorporado pelo romance, possibilita a mimetização desse reconhecimento. E o ser desvela-se não apenas pelo que narra, como experiência vivida, como pela assimilação do discurso específico dessa personalidade representado pelo romance. O plurilinguismo é uma das estratégias pelas quais o narrador, diarista fingido, pode desvelar-se ao leitor. Afinal, a opacidade da linguagem literária exige do leitor a atenção para essa constituição do sujeito que narra, também como discurso.

\section{O olhar para si como possibilidade de configuração textual}

A incorporação do diário, como gênero não literário, pelo romance traz consigo possibilidades de configuração, como a mimetização do formato mais reconhecível daquele, com especificação de datas, ou dias, ou com trechos curtos, sinalizando para a falta de planejamento e incompletude do texto, assim como assumir formatos que surpreendam pela fuga desses modelos. Exemplos modernos dessa incorporação menos mimética podem se parecer com configurações mais tradicionais do romance. É o caso de Diário de um pároco de aldeia, em que Georges Bernanos (2011) abandona as datações do presente e o tom da escrita do personagem se torna mais reflexivo, voltado a um leitor provável, do que confessional. Essa possibilidade de um diário perder o caráter de texto íntimo atinge um aspecto de ironia em Diário de um ladrão, autobiografia em que Jean Genet (2015) volta-se para o leitor, dirige comentários a prováveis "vocês", leitores que sabem quem ele é, como autor. Esse leitor-ideal de Genet também sabe que o livro não tenta ser um diário, mesmo sendo nomeado como tal: abrange um período de tempo recuado em relação à época de sua escrituração; em alguns momentos, faz menções a notas guardadas do passado.

Os dois exemplos citados, trazendo nos títulos a definição "diário", estão em 
limites opostos de fingimento: Bernanos faz ficção e Genet faz autobiografia. Entre um extremo e outro, existe a autoficção, como uma gradação que começa após a ficção pura e termina antes de se chegar à autobiografia, à confissão. A gradação permite que o autor se oculte ou se revele, o que também se reflete na configuração da obra, no gênero que o romance incorpora. A autoficção sinaliza para sua condição de texto que fala de um eu reconhecível como sendo o autor. Por ser ficção, há fingimento. Há graus de desvelamento ou de ocultação, mas o nível de conhecimento que o leitor tenha do autor pode acentuar essas possibilidades. Assim, o romancista Bernanos, em seu início de carreira, pode ser confundido com seu protagonista; já o polígrafo Genet, ao publicar seu Diário de um ladrão, é reconhecido pelo leitor-ideal naquela condição que Lejeune estabelece para a autobiografia: "Narrativa retrospectiva em prosa que uma pessoa real faz de sua própria existência, quando focaliza sua história individual, em particular a história de sua personalidade" (2014, p. 16). Ou seja, autor, narrador e protagonista são a mesma pessoa. $\mathrm{O}$ eu que narra sua história é reconhecido como o autor, sem que haja o fingimento característico da ficcionalidade. Quando há esse fingimento, adentra-se no âmbito da autoficção, e a obra passa a ser percebida como pertencendo a algum gênero especificamente ficcional, como o romance ou o conto.
É no sentido de indicar possibilidades dentro dessa gradação do "auto" para a "ficção" que Vincent Colonna estabelece uma tipologia para a autoficção. Dentre as diferentes formas de desvelamento desse eu, Colonna (2014, p. 39-66) identifica os seguintes tipos: fantástica, biográfica, especular, intrusiva (autoral). Os quatro tipos, no entanto, revelam limites estreitos: "Afirmei que a autoficção sempre tinha algo de especular" (COLONNA, 2014, p. 55), ideia que pode ser também reescrita, sem nenhuma dúvida, trocando-se "especular" por "autobiográfico".

Lejeune, que passa de uma visão redutora para outra mais ampla da autobiografia, entende como autobiográfico os textos em que um eu fala de si, mesmo ocultando-se, ainda que o autor fingisse não coincidir com seu protagonista. Ele também recorre à ideia da escritura como espelho: "O papel é um espelho. Uma vez projetados no papel, podemos nos olhar com distanciamento" (LEJEUNE, 2014, p. 303). O espelho, como possibilidade de um eu olhar-se e reconhecer-se, está na base para se reconhecer como "especular" certo tipo de autoficção. Ou seja:

Baseada em um reflexo do autor ou do livro dentro do livro, essa tendência da fabulação de si não deixa de lembrar a metáfora do espelho. O realismo do texto e sua verossimilhança se tornam, no caso, elemento secundário, e o autor não está mais necessariamente no centro do livro; ele pode ser apenas essa silhueta; o importante é que se coloque em algum canto da obra, que reflete então sua presença como se fosse um espelho (COLONNA, 2014, p. 53). 
Evidentemente, a possibilidade, mas não exigência, de o autor não aparecer como protagonista, figura central, indica uma possibilidade de configuração da obra; para ela, o diário certamente assumiria um aspecto mais inverossímil. A figura do autor como narrador-testemunha ou figura secundária tende a se configurar em formatos menos subjetivos, como o da biografia. Da mesma forma, esses podem assumir uma configuração menos verossímil, como a do texto escrito cujo foco narrativo mimetiza o relato oral. Nesse caso, o narrador não escreve, mas fala. E o texto não assume as formas que Bakhtin considerava que davam ao romance uma possibilidade de veridicção maior, ou aquela condição de querer se passar por real, que Hamburger (1986) considerava inseparável da narrativa em primeira pessoa. Notáveis em tal sentido são alguns contos de Luiz Vilela, de Contos da infância e da adolescência. Sabe-se que o autor, inúmeras vezes, está em cena, é personagem. Vilela olha seu passado, reconhece a vida da criança e do adolescente que foi ou que viu outros serem. Ora está em um canto da obra, ora ocupa seu centro.

O reflexo é uma constante na autoficção, mas não apenas nela. A ideia da escrita do eu como forma de reconhecimento ou de construção desse sujeito reflexivo está na ficção que se define como diário:

Quando me sentei pela primeira vez diante deste caderno escolar, procurei fixar minha atenção, recolher-me, como para um exame de consciência. Mas não foi minha consci- ência que vi com esse olhar interior ordinariamente tão calmo, tão penetrante, que não se detém no pormenor, que vai direto ao essencial. Parecia escorregar na superfície de uma outra consciência até então desconhecida de mim, um espelho turvo do qual temia ver surgir, de repente, um semblante - que semblante? o meu talvez?... Um semblante esquecido, novamente encontrado (BERNANOS, 2011, p. 13).

O trecho citado, de Diário de um pároco de aldeia, apresenta aquela característica de texto metaficcional, ou "livro dentro do livro", conforme especificado por Colonna (2014, p. 53), pois o narrador-protagonista, que não deve ser confundido com o autor, mas que evidencia reflexões deste, tem interesse por questões religiosas, o que explicita suas razões para se dedicar à escrituração de um diário. Exame de consciência, olhar para o semblante, o que se reflete nas páginas do diário é um eu conflituoso, antes esquecido e ora encontrado, através daquilo que Foucault define como cuidado de si, modo de o sujeito olhar-se como ação que modifica sua compreensão: "O cuidado de si vai ser considerado, portanto, como o momento do primeiro despertar" (2010, p. 9). A passagem do esquecimento para o reencontro, que passa pelo despertar apontado por Foucault, pode fazer do diário um espelho turvo, que ainda torna problemática a aceitação do semblante enxergado. A personagem de Bernanos sente essa dúvida. A escrituração em abismo, que se desenvolve falando de si e apontando o processo de sua formação, permite que esse aspecto turvo possa ser clarificado 
enquanto o texto avança. O inacabamento da personagem, por outro lado, pode ser uma característica explorada pelo romance em forma de diário.

Permanecer inacabado é uma atitude que problematiza a construção do diário real. Possibilita, assim, veridicção para um gênero que o mimetiza, que não se direciona para um final concludente. $\mathrm{O}$ gênero romance, no entanto, costuma apontar alguma conclusão. Podem-se aplicar a ele as palavras de Foucault acerca da atenção para si mesmo: "O cuidado de si é uma espécie de aguilhão que deve ser implantado na carne dos homens, cravado na sua existência, e constitui um princípio de agitação, um princípio de movimento, um princípio de permanente inquietude no curso da existência" (2010, p. 9). A inquietude, o movimento, esse aguilhão representado pelo cuidado de si implica uma duração. O ser não se vê inteiro nem definitivo em uma única visualização de seu reflexo; é preciso que essa clarificação, esse desvelamento, ocorra durante um processo de atenção, de cuidado de si, que se dá no tempo. No trecho citado, Foucault partia do princípio socrático de olhar para si mesmo como condição para o reconhecimento do sujeito por si mesmo. A identidade pode ser reconhecida através desse olhar, mas também pode ser construída no tempo. A forma do romance pode fingir uma inconcludência enquanto constrói um sentido para o qual se direciona.
Foucault se refere ao sujeito real. A atitude de o sujeito olhar-se, refletindo-se como em um espelho, é parte de uma hermenêutica que leva ao reconhecimento, ao desvelamento de si próprio. Exemplar em tal sentido é o modo como, em Diário de um ladrão, texto autobiográfico, Jean Genet fala da produção do texto como forma de interpretação de si mesmo:

Escrevendo, consegui o que procurava. Sendo para mim um ensinamento, o que vai me guiar não é aquilo que vivi, mas o tom que uso para relatá-lo. Não as anedotas, mas a obra de arte. Não a minha vida, mas a sua interpretação. É aquilo que a linguagem me oferece para evocá-la, para falar dela, traduzi-la. Construir a minha lenda. Sei o que quero. Sei para onde vou (GENET, 2015, p. 156).

Genet fala daquilo que justifica a elaboração de um texto voltado para si mesmo. Tratando-se de uma autobiografia, e sobretudo de uma figura conhecida por sua biografia peculiar, o autor poderia ter se concentrado no anedótico, no fato marcante, como o leitor que Machado de Assis interpela em Memórias póstumas de Brás Cubas poderia preferir. Mas Genet deixa evidente que quer construir-se como lenda. Constitui-se como um sujeito, por meio não apenas da narrativa da vida, mas da interpretação dela. E o autor tem consciência de que apenas a linguagem pode servir como espelho; não há tradução do sujeito fora dela. A linguagem, portanto, é condição para o sujeito constituir-se, assim como para a elaboração da obra de arte por ele perseguida. Sujeito e obra fundem- 
-se na configuração de um texto, de uma obra ensimesmada. Pode-se dizer em-si-mesmada, pois o si mesmo é tanto a obra que fala de sua própria elaboração, como o sujeito que interpreta a sua vida. O mesmo une as duas constituições, que se formam no tempo.

No trecho de Genet, chama a atenção a atitude de o autor não se voltar unicamente para o passado, ou para um si mesmo no presente, como sujeito já formado, mas para o fato de indicar uma possiblidade futura para si, o lugar para onde se vai, a lenda conforme o desejo, o querer-ser a antecipa. A construção da lenda demanda expectativas que precisam esperar pelo futuro. Genet exemplifica um cuidado de si não apenas como sujeito que olha para o passado, que fala de si no presente, mas que cuida do que ainda vai ser no futuro. Por isso, a sua autobiografia não termina nem indica um final, mas uma continuação, que não será feita, pois o autor está indicando a sua própria incompletude, voltada, no entanto, para um querer-ser que se torna cuidado e antecipação de si.

A relação entre passado, presente e futuro é uma das especificidades que possibilitam a experimentação no romance em forma de diário. Olhar para o agora, para o passado ou para o futuro pode resultar em configurações inusitadas, ao mesmo tempo, configura o tipo de cuidado de si que o sujeito assume. O tipo de cuidado resulta em sentidos diferentes para o sujeito, para a sua existência. É algo inseparável do sentido final do texto.

\section{O cuidado de si e a possibilidade de compreender}

Ao se falar em diário, chama-se a atenção para uma preocupação cotidiana com o olhar para si mesmo. O cuidado de si, como dizia Foucault, assume a condição de um aguilhão que faz o sujeito atentar para si mesmo, na busca de reconhecimento da própria identidade.

Trata-se de uma condição ambígua, quando se observa que o cuidado cotidiano de si, com tudo que ele acarreta, pode levar exatamente à impossibilidade de um sujeito construir uma identidade pessoal, que seja efetivamente sua e não apenas o reflexo da existência de outras pessoas. $O$ fato de o sujeito reconhecer-se enquanto ser-no-mundo faz da mundanidade, da presença dos seres em geral, a condição para que ele se delimite como um eu, aquele que pensa as coisas e, por isso, pode se delimitar como indivíduo. A inquietude, o aguilhão que o cuidado de si desperta, também já foi motivo de inúmeras reflexões. A filosofia assimila esse aguilhão de forma metódica, generalizada. A literatura é, no entanto, um universo em que tal reflexão encontra espaço para maior amplitude e liberdade. O cuidado de si literário percorre os gêneros diversos, não sendo característico apenas da escrita de si. Tanto Hamburger quanto Lejeune veem como problemática a possibilidade de essa assunção do eu ocorrer em textos ficcionais. Para a primeira, esse olhar 
para o eu, que imita os gêneros não literários nos quais o eu pode olhar para si ou falar de si, dá origem às formas especiais, gêneros que não se enquadram naqueles especificados desde a Poética de Aristóteles. Para o segundo, o fato de o texto falar desse eu faz com que ele se insira na categoria dos autobiográficos, o que pode incluir o diário, o blog, a autobiografia, entre outros. É preciso que se compreenda, a partir desses teóricos, que a autoficção também se enquadra na categoria de forma especial ou de texto autobiográfico.

Com isso, a autoficção é um cuidado de si, uma preocupação com a identidade e a compreensão das suas especificidades. Existem formas diversas de a literatura fazer isso, como ficção, e Bakhtin já havia chamado a atenção para isso ao definir o romance como gênero plurivocal, em que se pode falar de diversas maneiras. O romance em forma de diário, como autobiográfico, reconhece o sujeito, sua identidade ou personalidade, através de um olhar para o presente, na sua forma predominante. O passado aparece, como convenção do gênero romanesco, de forma indireta, alusiva, ou como reflexão sobre seu valor como causalidade para o ser. Da mesma forma, essa preocupação atrela o romance ao interesse pela trajetória da personagem: como ela se tornou o que é, mesmo que esteja voltada para o presente. Quanto mais mimetiza o formato próprio de diário, maior é a preocupação com a fragmentação e com a atenção para o presente.
O cuidado de si é assunto para uma complexa reflexão de Paul Ricoeur (2010), em Tempo e narrativa 3: o tempo narrado, na qual o filósofo expõe a preocupação com o presente como uma possibilidade de o sujeito fracassar no processo de reconhecer-se como autêntico. Ricoeur expunha alguns dos conceitos desenvolvidos por Martin Heidegger, em Ser e tempo. A preocupação do filósofo alemão era o ser, conforme inserido, lançado em uma temporalidade, o que faz com que sua formação e seu reconhecimento (ou desvelamento) ocorram em uma temporalidade marcada pela mudança, pela relação com o mundo, por meio da constatação da presença das coisas. Ricoeur, por sua vez, está preocupado com o modo como o ser percebe o tempo. A narrativa, para ele, resulta da necessidade de o ser explicar para si o que é o tempo. Novamente, esse ser está afetado por um aguilhão, que o leva a criar narrativas que expliquem o tempo. Em Ricoeur, a criação de narrativas procura uma definição para o tempo, à qual jamais se chega, e esse fracasso possibilita que a narrativa invente novas configurações, pois o aguilhão impede que se pare de buscar a explicação.

Ricoeur fala da preocupação com o tempo e de como obras consideradas precursoras dessa inquietação buscaram respostas. Assim, surgem Santo Agostinho e suas Confissões. Nelas, o autor explicita que vai mostrar-se assim como é. A autorreflexão agostiniana possibilita a atenção para os fatos, como causas, 
mas sobretudo para o que se é, como identidade. Está-se, evidentemente, no limite entre a narrativa e a reflexão, ambos como cuidado de si. O olhar interior, possibilitado por esse modelo de texto subjetivo, intimista, serve como base para que a ficção assimile o formato da narrativa em primeira pessoa, que trata do eu, ou que romances em terceira pessoa tenham como intenção o olhar para a formação de um outro. $\mathrm{O}$ diário garante ao romance a aproximação com o presente, tempo da narração, ou com o fato imediato, que ainda não se pode definir como causa de maneira precisa. É a inquietude que essa indefinição causa que leva o narrador a olhar para si, mas, ao mesmo tempo, prestar atenção aos fatos e relatá-los.

Heidegger chama de "cotidianidade" a atenção para o presente. Ela pode ser atenção para o si mesmo, mas, na maioria das vezes, limita-se ao cuidado para com o mundo circundante, sem que se reflita de modo profundo sobre ele. O presente, como cotidianidade, pode representar uma limitação do olhar para si mesmo. Tem-se, assim, a impessoalidade, que faz com que a existência transcorra sem um reconhecimento de si mesmo como completude. Ou seja: "O impessoal desenvolve sua própria ditadura nesta falta de surpresa e de possibilidade de constatação" (HEIDEGGER, 2012, p. 184), pois a convivência com o outro faz do sujeito um ser-com, e olhando para o modo como as demais pessoas vivem é que o sujeito acredita que o modo de ser coletivo é a possibilidade ideal. Fica-se na medianidade, pois estar nivelado ao outro é garantia contra o medo da surpresa ou de lutar pelo que se quer ou para o que se tem tendência. "Todo mundo é o outro e ninguém é si mesmo. $\mathrm{O}$ impessoal, que responde à pergunta quem da presença cotidiana, é ninguém, a quem a presença já se entregou na convivência de um com o outro" (HEIDEGGER, 2012, p. 185, grifos do autor), condição que ilude o sujeito acerca de sua autenticidade como ser. $\mathrm{O}$ fato de ser o outro significa não poder se reconhecer como autêntico ou estar iludido de que se é. Heidegger especifica essa condição de ser que imita o outro e a ele se condiciona:

Na utilização dos meios de transporte público, no emprego dos meios de comunicação e notícias (jornal), cada um é como o outro. Este conviver dissolve inteiramente a própria presença no modo de ser dos "outros", e isso de tal maneira que os outros desaparecem ainda mais em sua possibilidade de diferença e expressão. [...] Assim nos divertimos e entretemos como impessoalmente se faz; lemos, vemos e julgamos sobre a literatura e a arte como impessoalmente se vê e julga; também nos retiramos das "grandes multidões" como impessoalmente se retira; achamos "revoltante" o que impessoalmente se considera revoltante. O impessoal, que não é nada determinado, mas que todos são, embora não como soma, prescreve o modo de ser da cotidianidade (2012, p. 184, grifos do autor).

A impessoalidade como prescrição significa uma redução da liberdade. Ter que ser o outro, sem estar "somado" com ele, sem que possa chamar essa condição de "vida em coletividade", representa uma 
cegueira do ser para consigo mesmo, mas também para a possibilidade de o outro ser um si mesmo. "Essa medianidade, designando previamente tudo o que se pode e deve ousar, vigia e controla toda e qualquer exceção que venha a impor-se" (HEIDEGGER, 2012, p. 184), pois passa a exigir do outro o mesmo nivelamento que se exige de si. Ou seja:

Tudo que é originário se vê, da noite para o dia, nivelado como algo de há muito conhecido. O que se conquista com muita luta torna-se banal. Todo segredo perde sua força. $\mathrm{O}$ cuidado da medianidade desvela também uma tendência essencial da presença, que chamaremos de nivelamento de todas as possibilidades de ser (HEIDEGGER, 2012, p. 184, grifo do autor).

A cotidianidade é a preocupação com o presente e com aquilo que ele contém. $\mathrm{O}$ cotidiano, como preocupação com o presente, pode manifestar-se como cuidado de duas formas: ocupação e preocupação. A ocupação refere-se a tudo que compõe o mundo presente, maneável, para o qual nem sempre existe a constatação de se estar-com, ou seja, o ser preocupa-se com um mundo pelo qual é afetado; já a preocupação refere-se à copresença, ou seja, ao estar com os outros no mundo, ao ser-com aqueles outros que recebem uma atenção voluntária. A preocupação é mais ligada ao modo como o ser se reconhece como si mesmo do que a ocupação, que o desvia de seu foco. Aos dois modos de estar atrelado à cotidianidade, Heidegger chama "cura", que algumas traduções chamam de "cuidado". Ricoeur usa o termo "cuidado" não se referindo ao cuidado de si, como Foucault, mas ao que atrela o ser à cotidianidade e o vincula à medianidade. Cuidado seria a ocupação, o presente que encobre aquilo para o qual, efetivamente, o ser deveria olhar. "'Ocupar-se' da alimentação e vestuário, tratar do corpo doente é também preocupação" (HEIDEGGER, 2012, p. 178), pois a copresença caracteriza o ser-com. A ocupação, de outro modo, desconhece o outro como ser em sua presença e o vê apenas como maneável. Inserido na temporalidade, o ser olha para o passado, como forma de perceber sua identidade como ser idêntico a si mesmo, ou seja, reconhecível no presente pela semelhança com o ser do passado. No entanto, esse reconhecimento pode se tornar problemático, como mostra Heidegger: "Sem dúvida, ao dizer-eu, a presença refere-se ao ente que ela mesma sempre é. A autointerpretação cotidiana, porém, tem a tendência de se compreender a partir do 'mundo' das ocupações" (2012, p. 405). A relação entre ser sempre o mesmo, olhando-se para o passado em comparação com o presente, resvala na ilusão de que o si mesmo é autêntico, quando na verdade é impessoal, mediano. A inautenticidade desse eu decorre de ser ele impessoal, mediado pela atenção aos outros.

A temporalidade pode, contudo, representar a única possibilidade de o ser, como eu, reconhecer-se como um si-próprio, sem as ilusões do cuidado com a cotidianidade. Ser si próprio e não apenas si mesmo, no sentido de apropriar-se de si, como desejo. Afinal, o ser que se 
ocupa do presente e se reconhece através do passado parece ignorar a sua efetiva possibilidade de ser um si próprio, que é antecipar-se àquilo que se pretende ser. Ou seja, Heidegger coloca o futuro como tempo em direção ao qual esse sujeito que quer ser um si próprio deve olhar. Todo ser sabe que é finito, que a morte é indissociável de sua condição, no entanto, prefere colocar a morte como um fato que pode suceder apenas ao outro. Sua morte é sempre um evento provável, mas no qual se evita pensar. Heidegger insiste, assim, no ser-para-a-morte como possibilidade de antecipação, ou de ser-para algo que se espera. O espaço entre o presente e a morte é aquele lapso de tempo que se encolhe, enquanto o passado se distende e o presente apenas nos ocupa com os outros. No intervalo entre o presente da cotidianidade e a morte, é possível que o ser se projete como futuro, adote o querer-ser de tal forma que o eu possa ser autêntico, si mesmo conforme seu querer e suas inclinações. O ser projeta uma imagem daquilo que quer ser como uma identidade futura. $\mathrm{O}$ fato de antecipar-se a si mesmo pode fazer com que rompa com o medo de ser. Há fatores que impedem o sujeito de transformar o querer-ser em projeto e, finalmente, em ação. Um deles é o medo, provocado pela segurança que a impessoalidade garante. Outro é a indisposição para tornar possível o querer-ser. A cotidianidade e o cuidado com ela acabam substituindo a ação do querer-ser.
Antes de qualquer coisa, a antecipação pode representar a liberdade em relação à cotidianidade: "É no anteceder-se-a-si-mesma, enquanto ser para o poder-ser mais próprio, que subsiste a condição ontológico-existencial de possibilidade de ser livre para as possibilidades propriamente existenciárias" (HEIDEGGER, 2012, p. 260, grifos do autor), entendendo-se por "existenciário" aquilo que é cabível na existência. A liberdade não se constitui pelo rompimento com a ocupação. O ser não tem como deixar de ser-com, pois está lançado no mundo do qual é parte. A antecipação possibilita um rompimento com a impessoalidade, tanto no que se refere à cegueira em relação a si mesmo, quanto à impossibilidade de compreender o outro como ser. Heidegger fala da compreensão como relação em que o estar-com torna-se possibilidade para aquilo que se antecipa. Assim:

Compreender é o ser existencial do próprio poder-ser da presença de tal maneira que, em si mesma, esse ser abre e mostra a quantas anda seu próprio ser. [...] Como poder-ser, o ser-em sempre é um poder-ser-no-mundo. [...] Por que o compreender, em todas as dimensões essenciais do que nele se pode abrir, sempre conduz às possibilidades? Porque, em si mesmo, compreender possui a estrutura existencial que chamamos de projeto (2012, p. 204-205, grifo do autor).

Ter um projeto, como ser-para-a-morte, configura o ser que se quer-ser, ou seja, isso se torna uma abertura em relação à cotidianidade como algo que limita. A cotidianidade permanece, após 
a abertura, como possibilidade de compreensão, pois se atenta para o mundo não mais como algo impessoal: "No compreender de mundo, o ser-em também é sempre compreendido. Compreender de existência como tal é sempre compreender mundo. Enquanto presença fática, o seu poder-ser já sempre se transfere para uma possibilidade de compreender" (HEIDEGGER, 2012, p. 206-207), e, apenas compreendendo, o ser pode projetar-se e constituir tal projeto. O olhar para o mundo como uma cotidianidade que não é mais impessoal é a possibilidade de cura, de o ser tornar-se aquilo que de fato projeta.

\section{O amanuense Belmiro e a cotidianidade como fracasso}

O romance brasileiro da década de 1930 tem como uma de suas características a atenção para o impessoal, como possibilidade de um olhar para o outro que resulte em ação. Trata-se de uma visão comum ao romance engajado, que adota uma estética neonaturalista como forma de servir como documento que mostra o real. O romance engajado vê na preocupação com o social uma forma de libertação. Só se pode ser livre dentro das condições estabelecidas para o ser-com os outros.

Nessa perspectiva, o impessoal acaba se tornando a objetividade do romance neonaturalista daquela década. A atenção para o indivíduo e suas mazelas psicológicas, existenciais, era algo que a estética predominante negava. Nele, era possível olhar para uma identidade nacional que inclusive tal estética visava constituir. Olhar para o presente, com suas preocupações de natureza social, tornava relevante a estética que representava o real como documento.

Em 1937, Cyro dos Anjos lançou seu romance $O$ amanuense Belmiro, em meio à efervescência do romance regionalista de caráter sociológico. Naquele momento, a recepção positiva da obra causou surpresa:

Apreendido como "coisa nova" dentro de um panorama literário impregnado pelos mesmos temas e pelas mesmas preocupações, o livro de Cyro dos Anjos trouxe à tona a percepção que os romances sociais já não causavam o mesmo entusiasmo dos primeiros tempos, [...] a obra deu corpo ao outro lado da produção literária do momento, em tudo oposta ao romance social, a chamada literatura psicológica ou intimista, aparecendo, por isso mesmo, quase solitário dentro daquele contexto (NOBILE, 2006, p. 15).

Em A recepção crítica de O amanuense Belmiro, de Cyro dos Anjos (1937), Ana Paula Franco Nobile coloca o romance do escritor mineiro como oposto a uma tradição que valorizava a construção de uma identidade nacional, pela representação documental da realidade. O livro foi um sucesso de vendas e considerado o lançamento mais importante daquele ano. Foi de imediato objeto de inúmeros trabalhos de pesquisa.

Um dos objetivos recorrentes de tais pesquisas era evidenciar o caráter autoficcional de $O$ amanuense Belmiro. Chamava a atenção o fato de o autor haver 
publicado crônicas em jornal usando o pseudônimo Belmiro Borba, nome de seu protagonista. Em seguida, foi possível relacionar fatos ocorridos com o Belmiro da ficção que tinham estreita relação com a biografia do autor. Personagens do romance foram reconhecidas como sendo pessoas do trato pessoal do escritor. Os estudos procuraram, assim, entender a obra como autoficcional, para apenas posteriormente atentarem para sua filiação machadiana. Muito já se falou sobre a influência machadiana em $O$ amanuense Belmiro. Da mesma forma, o trabalho de Nobile também compara a técnica de romance em forma de diário de Cyro dos Anjos a Memorial de Aires, de Machado de Assis. Nos dois casos, a configuração como diário caracteriza as obras como intimistas, registros impressionistas do cotidiano. Em Machado, o olhar para o passado e a tentativa de compreender seus sentidos faziam com que o romance simulasse um diário íntimo que não era produzido para publicação; a configuração lembra a dos diários íntimos datados e formados mais por comentários que por narrativas. Em Cyro dos Anjos, a semelhança do diário com o romance machadiano faz pensar mais em obras que simulam autobiografias, com capítulos encimados por títulos e sem datação. Essa configuração é um dos elementos originais de $O$ amanuense Belmiro como romance que incorpora outro gênero. $\mathrm{Na}$ verdade, constitui uma característica do texto como obra "em abismo", que mostra uma mudança de interesses ao longo da sua produção. Por isso, perdeu o caráter de cuidado de si mesmo íntimo para se tornar uma exposição pública desse si mesmo problemático.

O romance de Cyro dos Anjos é composto por capítulos curtos, numerados, encimados por nomes. É uma fuga ao formato tradicional do diário. Logo nas primeiras páginas, o narrador-protagonista revela as suas intenções: não é a composição de um diário íntimo, mas de notas para serem usadas posteriormente, quando da elaboração de uma autobiografia. São anotações que o amanuense redige durante o expediente como funcionário em uma repartição pública onde nada se faz. Há tempo para o cuidado de si mesmo, na forma de redação de trechos curtos. No entanto, a preocupação em redigir notas sobre o passado é um pretexto para que o narrador possa contar a história de sua formação. Característica do bildungsroman, agora fingida, porque essas anotações do passado ocupam os cinco primeiros capítulos de um total e noventa e quatro. O que se tem diante do narrador-protagonista e do leitor, nesses cinco capítulos, é o passado em sua situação de formador de uma identidade presente. Belmiro é um amanuense antes da meia idade, homem sem importância, que mora na Rua Erê com irmãs mais velhas e solteiras. Veio de uma cidade do interior chamada Vila Caraíbas e reside desde a juventude em Belo Horizonte, descrita como provinciana. A passagem em que se fixa uma identidade como ser presente está loca- 
lizada no capítulo seis, em que Belmiro fala de sua cotidianidade:

Que tenho eu com os dias que a folhinha assinala? Há dois meses comecei a registrar, no papel, alguns fragmentos de minha vida, e noto agora que o faço em datas especiais. Encontro uma explicação plausível: minha vida tem sido insignificante, e no seu currículo ordinário nem faz, realmente, por onde eu a perceba. Habituei-me às coisas e seres que incidem no meu trajeto usual da Secretaria para o café e do café para a Rua Erê. Tais seres e coisas pertencem, por assim dizer, ao meu sistema planetário, e, entretido com eles, na sua feição mais ou menos constante, vou traçando quase que despercebidamente minha curva no tempo (ANJOS, 2006, p. 29).

O capítulo intitulado "Carnaval" aponta para as datas especiais em que Belmiro escreve. $\mathrm{O}$ evento representa, para quem tem uma rotina marcada pelo trabalho e pela atenção a amigos e familiares, a possibilidade de uma abertura em relação a ela. $\mathrm{O}$ personagem sai às ruas em uma noite de carnaval, acompanha um cordão carnavalesco, entra em um clube, bebe, e se deixa atingir por jatos de éter enquanto desfila. A inadaptação à situação faz com que sofra de modo intenso os efeitos da bebida e do éter. Naquele instante de atordoamento, uma mão branca de moça segura a sua e o acompanha. Belmiro vê, naquela moça, um mito das histórias infantis da sua infância: a donzela Arabela. Desde então, o personagem sente-se apaixonado pela moça, que na verdade se chama Carmélia e leva uma vida simples em uma rua comum.
Muito já se falou acerca da condição quixotesca do personagem, ao representar em uma moça comum o mito de uma donzela fechada na torre de um castelo e também ao fazer dessa moça a sua principal preocupação. Aqui, o sentido que Heidegger dá ao termo se enquadra no que ela representa como alguém que se presentifica, através da própria intenção que leva o personagem a buscá-la. Estar com Arabela torna-se uma ideia fixa. Belmiro vai passar seus dias imaginando-se como namorado dela. Ao longo do texto, a perseguição à moça, na forma de observá-la, ir a lugares que ela frequenta, encontra uma possibilidade de entendimento de sua condição através do amigo Glicério, que a conhece e frequenta sua casa, como amigo da família. Este personagem provê Belmiro de informações a respeito da moça, enquanto ironiza o modo como ele enxerga nela o mito de sua infância. Ele o informa a respeito do noivado e, posteriormente, do casamento da moça. Belmiro fracassa, sobretudo porque permanece em uma atitude passiva, de contemplação distanciada de seu objeto de desejo.

A condição quixotesca dessa mitificação de uma paixão comum representa, efetivamente, a possibilidade de fuga da rotina, daquela cotidianidade marcada pela impessoalidade, que leva Belmiro a nem mais prestar atenção naquilo que o rodeia. Nada é importante, a repetição das ações tomou a forma de condição da qual não se pode estar ausente. A descrição de uma identidade marcada pela 
indiferença em relação aos elementos da ocupação faz com que Carmélia, ou Arabela, apareça como uma preocupação. $O$ cuidado que se tem em relação a ela difere daquele que se tem com a repartição em que trabalha ou com a rotina estratificada. Ela desperta em Belmiro um querer-ser, uma vontade de ser-com, mas que se reduz a uma intimidade compartilhada apenas com o amigo Glicério.

A condição de Belmiro é quixotesca em sua visão idealizada do objeto de desejo. No entanto, muitos estudiosos já compararam Belmiro ao personagem Fausto, da obra de Goethe. O próprio autor chama a atenção para a semelhança no capítulo vinte, "Silviano e o problema fáustico", em que Belmiro encontra, sem querer, o diário do amigo Silviano, pessoa com pendores intelectuais, afetado, e que via no seu sentimento por Arabela um exemplo da irrealização do amor provocada pelo conhecimento, pela vida intelectual. $\mathrm{O}$ amor à vida perde lugar para o amor ao conhecimento, o qual, assim como para o Fausto da peça, é motivo para que não se consiga a espontaneidade e a superação do medo. Assim, no diálogo entre os amigos, Silviano explicita:

- Bem, o fáustico de Amiel se enquadra no definido por Spengler. Mas, quando disse que o "mito donzela Arabela" é um símbolo fáustico, não quis significar que você, Porfírio, homem de planície, ande em tais altitudes. Apenas me pareceu que essa aspiração do imaterial e do intemporal feminino, também minha, é, de algum modo, uma inquietação fáustica... (ANJOS, 2006, p. 66, grifo do autor).
A relação não é apenas com Fausto, mas também com o escritor Amiel, autor do conhecido Diário íntimo, que remete ao dilema assumido por Belmiro, após a noite de carnaval e o encontro com Carmélia, de voltar-se para o presente. A intenção inicial, de escrever um livro de memórias, torna-se a de registrar os dilemas da cotidianidade, com atenção especial, mas não predominante, para aquilo que se deseja. O querer-ser não se torna ação. O problema fáustico, apontado como tema central da narrativa, foi descrito por Vera Márcia Paráboli Milanesi, em Cyro dos Anjos: memória e história, como a subordinação do viver à reflexão. $\mathrm{O}$ caráter reflexivo, de quem possui o cuidado de si mesmo, faz de Belmiro um homem sem iniciativa:

Realmente, o problema está presente no protagonista, mas ele, ao contrário do Fausto, de Goethe, recusa-se a qualquer tentativa de reverter tal processo.

Belmiro mostra-se consciente de que a excessiva reflexão e insulamento prejudicam a sua vivência. Mas, apesar de mostrar possuir um "Mefistófeles" dentro de si, não adere às suas sugestões e raciocina, calcula e mede. Disso resulta um vaivém constante, uma alternância entre razão e emoção quase beirando à desagregação pessoal, dramaticamente percebida (MILANESI, 1997, p. 57).

Na verdade, trata-se de um homem não tão racional, mas vítima do medo, que impede que o seu projeto, o antecipar-se de uma vontade de ser no futuro, saia da condição de segredo. As atitudes de seguir a moça, de assediá-la de modo discreto, de ir ao Rio de Janeiro para ver a sua partida para a lua de mel não são 
indícios de racionalidade, mas de um homem que deixa de ser maduro para ceder a impulsos de um desejo que sabe que não vai ter coragem de concretizar. É infantil, como quando sonhava com Arabela na infância, mas não é a racionalidade do homem de letras.

Esse Belmiro quixotesco aventura-se discretamente pelas ruas de Belo Horizonte ou pelo cais do Rio de Janeiro, e essa vontade aparece como uma preocupação, que já transcendeu os limites da ocupação. A natureza ambígua de tal atitude aponta para um conformismo em relação ao ser-com os outros. Existe uma imagem de si como homem discreto, metódico, sem grandes paixões, que chega perto de se quebrar. Romper esse limite seria ultrapassar a linha da medianidade, a mesma em que estão inseridos os amigos com os quais passa horas no café, as irmãs mais velhas ou a amiga Jandira, possibilidade real de uma relação amorosa. A condição de medianidade, de olhar para si mesmo através da impessoalidade que o impede de ter atitudes que causariam estranheza, torna Belmiro um Fausto inicial, aquele que aparece no início da obra de Goethe, sozinho, à noite, clamando pelas sombras, possibilidade da morte por suicídio.

Em $O$ amanuense Belmiro, a cena de Fausto em que Mefistófeles aparece para o intelectual disposto a morrer é representada de modo irônico no quarto capítulo, "Questão de obstetrícia", em que Belmiro também se encontra no quarto, à noite. $\mathrm{O}$ desejo da morte, aqui, está reduzido ao desejo de poder dormir. O trecho que inicia o capítulo lembra o dilema de Fausto entre matar-se ou esperar:

Já estava palmilhando a terra vaga do sono, para frente, para trás, segundo a luta surda que se trava em nós, entre uma parte do eu, que aspira ao abandono, e outra que contra ele reage, talvez pelo receio inconsciente que inspira o adormecer, imagem da morte; ganhava-me o corpo uma doce lassidão, e o espírito se ia contagiando do torpor que afrouxa os nervos, apenas impressões vagas, prestes a se apagarem, me vinham das coisas, e a uma reminiscência tênue, quase a esvaecer, reduzia-se esta lembrança permanente com que, no estado de vigília, a memória sustenta, a cada instante, nossa precária unidade psíquica, ligando o movimento que passou ao momento presente (ANJOS, 2006, p. 23).

O monólogo de Fausto é também uma luta surda:

A novas margens chama nova aurora.

Flutua um carro flâmeo a mim, sobre asas aéreas!

Prestes me sinto a penetrar a altura,

A me entranhar em órbitas etéreas,

Novas regiões de atividade pura (GOETHE, 1987, p. 51).

Mefistófeles aparece na forma de um cachorro, que amedronta o persona- gem para, em seguida, tornar-se o ser que possibilita a ele romper os limites impostos pelo conhecimento e pela reflexão: 
Pois vês! É um cão, não é nenhum fantasma.

Hesita, rosna, arrasta-se no chão,

Rabeia. Tudo isso hábito de cão (GOETHE, 1987, p. 66).

Em $O$ amanuense Belmiro, a cena se repete de modo mais cotidiano:

De corpo e espírito, achava-me, pois, preparado para o repouso e já me aconchegava, repetindo, instintivamente, as posições do embrião no ventre materno, quando, arrancando-me daquele suave quebranto, o cão dos fundos se pôs a ladrar, com um método que indicava disposição sólida de latir pela madrugada toda. Previ a catástrofe, em sua extensão, e repreendi-me por já não ter ministrado uma "bola" ao canino demônio (ANJOS, 2006, p. 23).

A alusão à cena da aparição de Mefistófeles, na forma de um "canino demônio", na obra de Goethe, é feita de modo irônico, pois a reação do homem de ideias é impulsiva: atirar um sapato velho pela janela, que atingisse o cão ou o fizesse parar de latir. A expulsão da presença do demônio, como cão, indica a atitude corriqueira de Belmiro de evadir-se das ações que necessitam de coragem e saída da impessoalidade, da mesma forma, a fuga da reflexão profunda, que transcenda $o$ impessoal. O silenciamento do cão, nas páginas iniciais da narrativa, já serve como um indício daquilo que Belmiro é, como ser que é reconhecido como tal ao longo da narrativa. A cena especifica a personalidade desse homem que havia se definido como uma "Borba errado", em capítulo anterior, por não ter herdado o caráter pragmático de seus antepassados. Borba, aqui, remete ao personagem de Machado de Assis, que também veio do interior e prefere a reflexão à ação. Contra o otimismo de Quincas Borba, o amanuense Belmiro Borba apresenta uma visão desencantada, em que as ações não se concretizam porque o personagem não encontra sentido nelas nem em sua cotidianidade. A ação de atirar o sapato é irrefletida, não representa a possibilidade de compreensão do outro de que fala Heidegger. É uma atitude como a de seguir a moça pelas ruas; na verdade, o medo de ter que agir de uma forma em que se desconheça como uma identidade.

Belmiro oscila entre o sonho, o desejo por sua Arabela, que o faz agir de modo irrefletido, mas sem uma expectativa de realização, e a realidade cotidiana, em que apenas repete uma rotina que não o leva ao cuidado de si mesmo como ambicionara, ao querer escrever suas memórias, nem ao cuidado de si próprio como cura, através da compreensão de como poder-ser aquele que havia projetado. As duas expectativas são frustradas: não escreve o livro de memórias nem conquista a moça desejada. Tais possibilidades de realização significam, para o homem maduro que não realizou nada de significativo em sua vida, o projeto de um ser-para-a-morte, a antecipação de um Belmiro escritor ou marido.

O projeto de escrever memórias, mesmo sendo de um homem comum, 
corresponde a uma fuga ao impessoal, mas geraria estranheza e o personagem estaria fora de suas ocupações. Assim, a cena em que Belmiro conhece Carmélia, sua mitificada Arabela, no carnaval, pertence também à esfera do sonho, do delírio provocado por substâncias químicas, forma de encorajamento que o priva da discrição típica da medianidade. Passado o efeito, já não há a coragem, apenas um querer para o qual não há predisposição. Em ambas as expectativas, a cotidianidade, primeiramente como ocupação, rotina de trabalho burocrático que levava Belmiro a escrever apenas em datas especiais, depois como preocupação de querer estar-com Arabela, mas temendo a reprovação por parte da moça e do círculo de amigos, acaba por não permitir a saída de um mundo de ocupações imediatas. A rotina de encontros com amigos, atenção para as doenças das irmãs já idosas, o trabalho burocrático evidentemente sem resultado como obra ou facticidade, tudo impede Belmiro de fazer de seu ser-para-a-morte uma antecipação transformada em compreensão de si mesmo e do mundo. Por isso, o fracasso e o pessimismo encerram a obra:

Previdente e providente amigo! Esqueceu-me comunicar-lhe que já não preciso de papel, nem de penas, nem de boiões de tinta. Esqueceu-me dizer-lhe que a vida passou e nada há mais por escrever.

Ai de mim! É necessário, porém, fazer qualquer coisa, para empurrar os presumíveis trinta e dois anos que me restam. Trinta e dois nãos, sim. Em média, os Borbas vão até os setenta, mesmo com o coração descompensado. Acho-me pouco além do meio da estrada, e parece-me, entretanto, que cheguei ao fim (ANJOS, 2006, p. 228).
Belmiro está interessado, ao final, em alguma forma de ocupação que torne esses 32 anos algo passável. Por "qualquer coisa”, entende-se a ocupação, a impessoalidade, que sirva apenas para manter a condição de estar-no-mundo, mesmo que isso não signifique compreensão nem preocupação consigo ou com o outro. Trata-se do cuidado como ocupação, da impessoalidade como forma de suportar o tempo. O personagem está renunciando ao cuidado de si, através da elaboração de um diário, para fugir do olhar interior e atentar apenas para o impessoal. Não haver mais nada para escrever significa o fracasso como ser, a ausência de sentido, até mesmo pela desistência de querer-ser. Como disse Heidegger, o impessoal é o ninguém. Da mesma forma, o ser ninguém não significa:

Sentido significa a perspectiva do projeto primordial a partir do qual alguma coisa pode ser concebida em sua possibilidade como aquilo que ela é. O projetar abre possibilidades, isso é, o que possibilita. [...] O ente só "tem" sentido porque, previamente em seu ser, ele se faz compreensível no projeto ontológico, isto é, a partir da perspectiva de ser. É o projeto primordial de compreender ser que "dá" sentido (HEIDEGGER, 2012, p. 408-409).

A falência do projetar-se, tímido e temeroso, levou Belmiro a abandonar até mesmo o projeto inicial, em que poderia fazer-se compreensível como ser. $\mathrm{O}$ passado, pelo qual o sujeito A olha para sua existência em momentos anteriores, como forma de definir quem é, também já não lhe interessa. Nada lhe resta a não ser o abandono à cotidianidade, como fuga. A possibilidade da cura, 
por meio do cuidado de si mesmo e do antecipar-se a si mesmo, como projeto de ser que se constitui, não se concretiza para Belmiro, pois ele apresenta o medo e a passividade que o impedem de agir compreensivamente.

A condenação a uma existência inautêntica, sem sentido, manifesta-se na frase final do livro, em que Belmiro pergunta a um colega de repartição o que eles podem fazer. A impossibilidade de uma decisão pessoal recoloca o personagem na condição de ser o outro, o ninguém, perdido na impessoalidade:

Quando um tombava, parecia queda de gameleira ferida pelo raio. Não morriam aos poucos, vendo o corpo consumir-se lentamente.

- Que faremos, Carolino amigo? (ANJOS, 2006, p. 228).

Morrer lentamente é uma expectativa de torpor e Belmiro prefere, como Fausto, não ter que suportar o tempo que resta para viver uma existência sem sentido. Fausto estava decidido a matar-se, antes de aceitar as promessas de Mefistófeles. Belmiro expulsou, de antemão, qualquer possibilidade efetiva de experimentar a coragem. Precisa agora da cotidianidade como uma distração que o faça suportar os anos que lhe restam, já que também não dispõe da coragem para matar-se. A ausência de sentido torna esse tempo que resta até a morte não um intervalo no qual se constrói o sentido, a autenticidade, o si próprio, pois aqui a luta não é para transcendê-la, mas para estar inserido no que ela representa, como finitude e aniquilamento. Estranha forma de se projetar a morte, em que não há nada a fazer antes que ela chegue. Belmiro, como diria Heidegger, é ninguém, pois é impessoal. Não possui um projeto de ser que o faça transcender a ocupação através da preocupação. A cotidianidade é um antídoto contra a percepção da passagem do tempo, mas não é capaz de torná-lo alguém. A ocupação, como distração, cuidado do outro, reduz Belmiro à impossibilidade de constituição de sentido para si.

Se a ausência de sentido pode ser, de fato, uma destinação para o ser que olhou para si e desistiu desse olhar, ou se ser ninguém implica a falta de identidade, como um A que possa reconhecer-se quando de novo olhar-se, são problemas que dizem respeito ao que se possa chamar de ter identidade. O ser, mesmo inautêntico, impessoal, certamente, pode reconhecer-se como idêntico a si, pode reconhecer-se como não possuidor de um sentido e, por isso mesmo, ainda perceber a semelhança consigo mesmo, que identifica o ser, mesmo que se veja como ninguém. Belmiro quer, ao atentar para o seu fracasso, criar as condições para ser estável, pois o medo o impede de projetar um si próprio diferente daquele que reconhece como seu eu ao final da narrativa. Sem projetos, o presente é sua ocupação, porém não mais consigo mesmo, através da redação de um diário; o olhar está voltado, então, para o cotidiano como impessoalidade. O olhar interior, por si só, como queria Heidegger, não pode construir a existência autêntica. Insistir 
nele seria uma forma de reafirmar uma identidade como fracassado.

\section{Considerações finais}

O diário, enquanto forma de preocupação com o presente, é assumido pelo romance como forma de atentar para $o$ cotidiano, sem o distanciamento épico. Tal preocupação com a narrativa de fatos que parecem próximos da narração, ainda não devidamente compreendidos, possibilita ao romance intensificar a natureza dos conflitos humanos; a incompletude do diário está adequada à falta de respostas para questões existenciais. Bakhtin foi lúcido ao perceber o quanto a proximidade com o presente cotidiano representava como possibilidade de 0 romance abordar questões humanas. Se existe a preocupação com a completude, própria da autoficção que adota a forma de autobiografia, a incompletude manifesta-se na incorporação de gêneros marcados pela inconcludência, como carta e diário. Tais formas fazem com que a autoficção mimetize conflitos humanos, como a dúvida entre a ação e a passividade, entre a coragem e o medo, a vida e a morte.

No caso de um romance que, desde o lançamento, foi identificado como obra que fala do próprio autor, a atitude de atribuir ao autor os sentidos que o texto constrói para o personagem é algo ingênuo. Seria transformar ficção em confissão; fazer da experiência de Cyro dos Anjos, como amanuense e morador de cidade provinciana, a mesma vivenciada por um narrador-personagem que se define como medroso e fracassado. Por isso, a autoficção precisa que se atente para suas especificidades como configuração. $\mathrm{O}$ diário que se tem em mãos é obra de ficção; seu formato altera as convenções do gênero; é romance, mesmo que se tenha tantas vezes apontado semelhanças com a biografia do autor. Essa relação entre o distanciamento épico e a enunciação subjetiva do lírico é marca da autoficção e uma característica que a torna instigante para o leitor e para o crítico. Adotar o diário e não a autobiografia como gênero que configura o romance é estratégia que possibilita a incompletude até mesmo como possibilidade de configurar os limites entre autobiografia e ficção; silenciar sobre o que não se pode dizer quando se fala de si mesmo; estabelecer até que ponto o espelho pode distorcer a imagem de quem o contempla.

O diário possibilita desdobramentos técnicos ao romance, formas variadas de se imitar o gênero. Cyro dos Anjos, em $O$ amanuense Belmiro, retoma o modo machadiano de narrar em forma de diário, mas o reformula, ao fazer com que sejam páginas intituladas, para eventuais leitores. Modelo estranho, que resulta em uma atitude mais reflexiva por parte do narrador-personagem, que evidencia uma preocupação em olhar para si mesmo, estabelecer uma identidade, seja como mais um Borba, ou apenas como Belmiro. Estabelecer quem é Belmiro 
significaria olhar para o passado e reconhecer a permanência de elementos que configuram uma identidade. Mas Belmiro é surpreendido pela possibilidade de construir a si próprio, através da projeção do querer-ser. $\mathrm{O}$ sonho de possuir Arabela, de romper com sua solidão e de suas irmãs, forma também de não ser mais um Borba, mas um Belmiro autêntico, o estimula a atentar para o presente; a autobiografia vira um conjunto de notas sobre o cotidiano. $\mathrm{O}$ esforço por conciliar o sonho, o projeto de querer-ser, com a cotidianidade rasteira, impessoal, do homem que cuida das irmãs, conversa com amigos, passa os dias em um trabalho improdutivo e desestimulante, que é revelado nas anotações, acaba por resultar em constatação do fracasso. Não apenas o projeto de ser fracassou; ser impessoal significa ser ninguém, e a única atitude possível é a do niilista que apenas suporta a existência, sem estar atrelado a ela por qualquer sentido.

Portanto, a ocupação com o presente, típica do diário, é um dos elementos que aprisionam Belmiro na cotidianidade. Afinal, a possibilidade de reconhecimento de si mesmo não significa, de imediato, que esse ser reconhecido faça algum sentido. Para Heidegger, a preocupação com o futuro, com o projeto de ser, pode possibilitar o sentido para a existência. Belmiro desistiu do projeto de ser amante ou marido; da mesma forma, desistiu de ser um escritor, de deixar uma obra escrita que o livrasse da morte como aniquilamento total. Sem um projeto de ser, sem olhar para o futuro senão como desejo do aniquilamento, resta o desespero, a falta de respostas para a vida.

A falta de respostas, como incompletude, é característica do diário como tal e de como o romance o incorpora. Cyro dos Anjos deixa o fracasso de seu narrador-personagem como momento final, como última nota, mas também como inconcludência. A identidade de Belmiro, traçada na obra, como fracassado, leva o leitor a projetar para o futuro dele o medo, a atitude desiludida de quem desistiu de qualquer projeto. $\mathrm{E}$ a cotidianidade seria, para ele, ao contrário do olhar para si que o diário possibilita, como um espelho, no qual o ser pode reconhecer a permanência e a mudança ao longo do tempo e assegurar a construção de seu projeto, apenas uma forma de obscurecimento, de cobrir o espelho e olhar apenas através da janela da impessoalidade, ou seja, ocupação que engana e torna os dias passáveis.

\section{The care of the present as an obstacle to the construction of the sense of existence, in $O$ amanuense Belmiro}

\section{Abstract}

Bakhtin deals with the plurilinguistic nature of the novel, paying attention to the assimilation that this makes of diverse genres. The diary format allows the novel to attend to the present, approaching the narrative of the daily life and results in the incompleteness of that genre. If self-care enables the recognition of one's own identi- 
ty, according to Foucault, the diary, looking at the present, exemplifies moments of this care. Heidegger, however, points to the care of the present as an obstacle to the constitution of an authentic being whose existence makes sense; Only attention to the future, as a project of being, can free the being from the impersonality of everyday life. This contradictory nature of the diary is observed here in the novel $O$ amanuense Belmiro, by Cyro dos Anjos, which shows a reflective man. In it, the occupation with the everyday encloses the being in the impersonality and generates in him the fear of accomplishing his project. Being fails and makes occupation with the present a way to withstand the meaninglessness of existence.

Keywords: Diary. Cyro dos Anjos. Identity. O amanuense Belmiro.

\section{Referências}

ANJOS, Cyro dos. O amanuense Belmiro. São Paulo: Globo, 2006.

BAKHTIN, Mikhail. Teoria do romance I: a estilística. São Paulo: Editora 34, 2015.

BERNANOS, Georges. Diário de um pároco de aldeia. São Paulo: É Realizações, 2011.

COLONNA, Vincent. Tipologia da autoficção. In: NORONHA, Jovita M. G. Ensaios sobre a autoficção. Belo Horizonte: Editora UFMG, 2014. p. 39-66.

FOUCAULT, Michel. A hermenêutica do sujeito. São Paulo: WMF Martins Fontes, 2010.

GENET, Jean. Diário de um ladrão. Rio de Janeiro: Nova Fronteira, 2015.

GOETHE, Johann Wolfgang von. Fausto. Belo Horizonte: Itatiaia, 1987.
HAMBURGER, Käte. A lógica da criação literária. São Paulo: Perspectiva, 1986.

HEIDEGGER, Martin. Identidade e diferença. In: Conferências e escritos filosóficos. São Paulo: Nova Cultural, 1996. p. 171-200

. Ser e tempo. Petrópolis, RJ: Vozes; Bragança Paulista, SP: Editora Universitária São Francisco, 2012.

LEJEUNE, Philippe. O pacto autobiográfi$c o$ : de Rousseau à internet. Belo Horizonte: Editora UFMG, 2014.

MILANESI, Vera M. P. S. V. Cyro dos Anjos: memória e história. São Paulo: Arte \& Ciência, 1997.

NOBILE, Ana Paula Franco. A recepção crítica de $O$ amanuense Belmiro, de Cyro dos Anos (1937). São Paulo: Annablume, 2006.

RICOEUR, Paul. A memória, a história, o esquecimento. Campinas, SP: Editora da Unicamp, 2007.

Tempo e narrativa 3: o tempo narrado. São Paulo: WMF Martins Fontes, 2010. TELES, Adriana da Costa. O labirinto enunciativo em Memorial de Aires. São Paulo: Annablume, 2009. 